\title{
Legal Politics Learning Process in Implementing Characters in The Course of Pancasila in Higher Education in the Pandemic Era Covid 19
}

\author{
Hassan Suryono ${ }^{1,2, *}$ Raharjo $^{1}$ \\ ${ }^{1}$ Pancasila and Civic Education Department, Faculty of Teacher Training and Education, Universitas Sebelas Maret, \\ Indonesia \\ ${ }^{2}$ Head of the center for the study of radicalism and terrorism; \& Coordinator of Pancasila Education Course in \\ Universitas Sebelas Maret \\ *Corresponding author. Email: hassansuryono@staff.uns.ac.id
}

\begin{abstract}
This paper aims to explain how the learning strategy is to instill the values of Pancasila character values in the Pancasila course in Higher Education. The method used is a descriptive method that explains the current or actual situation. The analysis used is the Dimension of Effectiveness in the Implementation of Political Law which regulates learning during the COVID-19 pandemic. The results of the analysis produce a strategy to instill the character of Pancasila values that should be implemented since planning, implementation and evaluation. The strategies used are (1) determining general attitudes and skills to be achieved, (2) determining the learning outcomes of the course, (3) determining the substance of the study / lecture material, (4) determining the implementation with the right teaching method. In teaching exemplary learning, the lecturers become role models that are always shown to students in the form of pictures, videos, with positive attitudes and behaviors using online teaching material designs and appropriate online models of learning (Internet based), for example) learning videos with PowerPoint / animation,) learning videos with a non-narrative video / film approach, learning videos with a Narrative Videos / Films.
\end{abstract}

Keywords: Legal politics, the value character of Pancasila and the learning model

\section{INTRODUCTION}

Universities / schools, in essence, are not just places for "transfer of knowledge". As stated, schools are not merely places where teachers convey knowledge through various subjects. Schools are also institutions that strive for valueoriented enterprises and learning processes.[1]

On January 5, 2010 the Director General of Higher Education issued a circular number 06 / D / T / 2010 concerning the Implementation of Pancasila Education Lectures in Higher Education. The attachment to the letter contains a competency-based Pancasila Education learning model with an active student approach (Student Active Learning / SAL). The consequence of this approach is a paradigm shift from being centered on lecturers to being centered on students from teaching to learning. From oneway delivery to active participation. From knowledge transfer to value transfer. So in Pancasila Education learning there is a change from how lecturers teach well towards how students can learn well. Meanwhile, the learning approach model that can be used is Contextual teaching and learning (CTL)., Problem based learning (PBL), demonstration, case study., directed teaching., group learning., information seeking process., study groups., jigsaw learning., competitive learning., snowball and discussion.

Which learning model will be applied in Pancasila Education, this needs to pay attention to the objectives to be achieved., The nature / material of the material, the condition of the students., The existing facilities and infrastructure. The more important thing is that the learning model must be able to develop the value of Pancasila values in the learning process. The value in question is the value of faith., Devotion., Peace., Justice., Equality., Harmony., Civility., Unity of unity, consensus., Wisdom and prosperity, so as to foster love for the homeland, be responsible and do good deeds. which is beneficial for the nation and country. It is not easy to determine which learning model can reflect the values of Pancasila, it is necessary to analyze the contents of each learning model and continue with the synchronization of concepts, and the values contained in Pancasila with the learning model.

The hope above cannot be implemented because there have been major changes in conditions due to individual 19. The Covid-19 pandemic requires face-to-face education in class (offline) to be replaced with online methods carried out at home (online). The implementation of online methods in education is deemed less conducive. 
Especially in the process of internalizing and cultivating the character values in Pancasila. In order to be able to instill the character of the values of Pancasila in the Pancasila course in Higher Education, a strategic effort is needed in instilling the values of Pancasila, thus obtaining an appropriate and effective method and learning media in instill the character of Pancasila in Pancasila courses in Higher Education.

During the Covid-19 epidemic, the values of Pancasila were very much needed in order to make a strong community and to stay in synergy. Pandmi Covid-19 has turned various aspects of life into chaos. No exception, education is also one of the aspects affected. Pademi Covid-19 requires the world of education to change the learning methods that have been carried out so far. The learning method applied is an online method to break the chain of Covid-19 transmission. That education is a conscious and planned effort in creating an atmosphere of the learning process so that students are active and creative.[2] As a result of the impact of the Covid-19 pandemic, the active learning process becomes passive if there is a lack of guidance and supervision. As a teacher, it is necessary to instill character values in online learning. Pancasila values are very suitable as forming student character who can still develop their potential.

Education that contains Pancasila values is the main shield against these challenges and threats.[3] Value is a historical and social driving force, value is an appreciation or a quality for something that is the basis for determining human behavior. Pancasila contains values including: religious spirituality, self-control, personality, intelligence, noble character, and skills in the learning process. Because Pancasila contains values such as divinity, humanity, unity, democracy and justice, it should be used as a defense shield. From some of the theoretical foundations above, here the author will try to analyze the role of Pancasila values in shaping the character of elementary school students during the Covid-19 pandemic.

\section{METHODS}

The method used in this research is legal research and library research. Legal research is a scientific event, which is based on methods, systematics, and certain thoughts, which aim to study one or several phenomena of certain laws, by analyzing them. Apart from that, an in-depth examination of the legal facts is also carried out, to then seek a solution to the problems that arise in the symptoms concerned [4] Then the literature study was carried out in the form of utilizing reference sources and literature review.[5] The data or materials needed in completing library research come from library sources in the form of books, encyclopedias, dictionaries, journals, documents, magazines, and so on.[6]

\section{RESULT AND DISCUSSION}

\subsection{LEARNING BASED ON PANCASILA VALUE CHARACTER}

Regarding character-based education, character education will only become a discourse if it is not understood more completely and thoroughly in the context of our national education. In fact, character education that is partially understood and not right on target is actually counterproductive to the character building of students. A partial approach that is not based on a solid pedagogical approach instead of instilling the values of virtue in children, instead plunging them into immoral behavior.[7] Formation is a part of value education through schools which is a noble effort that urgently must be done. There are 18 points of educational character values: responsibility, social care, environmental care, fond of reading, love of peace, friendly / communicative, respect for achievement, love for the homeland, national spirit, curiosity, democracy, tolerance, honesty, discipline, creative , Hard work, Religious, Independent. Character building is part of value education through school, which is a noble and urgent effort to do. In fact, if we talk about the future, schools are responsible not only in producing students who excel in science and technology, but also in identity, character and personality. And this is relevant and contextual not only in countries that are experiencing a character crisis like Indonesia, but also for even developed countries.[8] Character education, in principle, can also be done within the family. As Phillips suggests, families should return to being "schools of love", schools for affection.[9]

The wider community environment clearly has a major influence on the success of instilling aesthetic and ethical values for character building. From an Islamic perspective, the social situation with the value system it adopts affects the attitudes and point of view of society as a whole. If their value system and views are limited to the "here and now", then their efforts and ambitions are limited to the here and now.[10]

Learning is basically a curriculum in action. Pancasilabased learning is the implementation of a curriculum that contains the values of Pancasila. The Pancasila Education Curriculum was developed based on the concepts contained in Pancasila, namely the concept of the essence of human existence, pluralistic, harmony, mutual cooperation / kinship, integralistic, populist, and nationality. Pancasila-based learning references are mastery learning or complete learning which is based on the recognition of student differences in achieving learning objectives. Learning in practicing the values of Pancasila values rests on learning outcomes sequentially from the part of the Pancasila values, namely the values of the first, second, third, fourth and fifth precepts. For example, students can learn competence from the second precept value, if they have completed studying the competence from the first precept value. and so on.[11] 
Pancasila education learning strategies should be synchronized with the concepts / materials and values contained in Pancasila and this is a common task to formulate this meeting. So that this meeting will produce a Pancasila-based learning model for all courses in Higher Education (Macro) and Models Pancasila-based learning for the Pancasila course itself. In this way, the responsibility to develop Pancasila values is not only the responsibility of lecturers in Pancasila Education courses, but also the responsibility of all lecturers who teach courses in Higher Education.

The learning process of Pancasila Education in its implementation is complete, unique., Democratic., Elegant., Global., Active., Innovative., Creative., Effective., Fun., Happy and weighty, consensus and wise. There is equality and harmony between Lecturers. and students on the basis of civility, so as to form unity and integrity.

The form of learning process activity is by providing learning experiences to students in order to achieve predetermined competencies, the lecturer must share and process information by conducting face-to-face lectures, discussions, seminars., Giving exercises, responsiveness, assignments / homework / lectures. small group.

To encourage students to grow and develop awareness of understanding and practice of the importance of pluralism., Integralism and nationality, in order to maintain the four pillars of the pillars of the establishment of the glory of the Indonesian nation, namely the Republic of Indonesia which is guided by the 1945 Constitution of the Republic of Indonesia with its Pancasila and enthusiasm Unity in Diversity

The Director of Learning and Student Affairs of the Ministry of Education and Culture published the Pancasila Education Module / E-Book for Non-Conventional Learning or as material for Distance Education (2012) this book was published aimed at meeting two important issues in education, namely learning methods and materials. With the teaching material in the form of an e-book, it is hoped that the learning method will be more interesting and make students not easily bored. Materials will also be easily developed because they can be linked to digital assets, such as video presentations, papers, animations, and so on.

\subsection{CHARACTER OF PANCASILA VALUE IN LEGAL POLITICS}

The government has realized the importance of character education as proclaimed in the 2013 curriculum. [12] The implementation of the 2013 curriculum is expected to be able to become students who have noble, knowledgeable, creative, independent, and become democratic and responsible citizens according to the goals of the National Education. Character means having positive qualities such as caring, fairness, respect for others, willingness to forgive, being aware of life, community and so on. Previous research has shown the optimism of respondents from both teachers, principals and students in the learning process because it encourages honest and polite actions and attitudes, which means that it can be said that the results of character education in the 2013 curriculum.

The word character comes from the Greek charassein, which means to engrave (paint, draw), such as people who paint paper, sculpt rock or metal [Abdusshomad, Alwazir. (2020). The Effect of Covid-19 on the Implementation of Character Education and Islamic Education. Journal of Education, Social and Religion. Vol 12 (02)]. In term, character is defined as human nature in general, where humans have many traits that depend on their own life factors [Mu'in, F. (2011). Character Education Theoretical Construction \& Urgency Practice of Pregressive Education and Revitalization of the Role of Teachers and Parents. Yogyakarta: ArRuzzmedia]

Character education is education that is based on core ethical values rooted in a democratic society, in particular, respect, responsibility, trust, justice and honesty, care, and civic virtue and citizenship.[13] Character education refers to the process of cultivating values, in the form of understandings, procedures for caring for and living these values, and how a student has the opportunity to be able to practice these values in real terms.[14]

Pancasila is a basic value in the form of absolute principles, something that cannot be questioned anymore, to realize these basic values in a life, instrumental values are needed as a general implementation of basic values which are usually in the form of social norms and legal norms which are concretized by the government. and determinants of policy. The instrumental value is dynamic and contextual. The translation of the basic values is in accordance with the development of society. The realization of these instrumental values is in the form of practical values as a manifestation of the spirit that exists throughout society, be it government, legislative, judicial, and citizen institutions. and all components of Indonesian society. Pancasila is the basis of the state, the ideology of the nation and the philosophy and outlook of life of the nation, which contains basic values, instrumental values and practical values.[15] The formulation of Pancasila was the result of the efforts of the heroes and the founders of the nation. Since the Indonesian state was founded until now, the Indonesian state has remained firmly adhering to Pancasila as the basis of the state. As the basis of the state which forms the basis of the state in facing various challenges that threaten the country both from within and outside. In addition, the negative influences of foreign cultures can be filtered using Pancasila values. The role of Pancasila values is very important in maintaining the character of the Indonesian Indonesian nation itself. With the existence of Pancasila, the Indonesian nation has guidelines in life.

Pancasila values need to be instilled from generation to generation in order to maintain the quality of the nation in the future. The inculcation of these values can be through education about Pancasila at various levels of education [16] Pancasila education is one way to shape a nation's character that is moral and has broad insight into life. However, the values of Pancasila must continue to be 
implemented in all aspects of the life of the Indonesian nation because the values of Pancasila are inherent in the bearers and supporters of the values of Pancasila itself, namely the society, nation and state of Indonesia.

The actual character values are also stated in Law Number 20 of 2003 concerning the National Education System which aims to develop students to become human beings who believe and have devotion to God Almighty, have noble character, are creative, independent and responsible (Article 3 of Law No. 20 in 2003).[17] Seeing from the goals to be achieved this negates that showing the need for character education in the Indonesian education system. Character values are also included in the MPR Decree No. VI / MPR / 2001 on Ethics of national life, especially in the ethics of national life, namely honest, mutual care, understand each other, respect each other, love each other, help each other, between citizens and between nations (CHAPTER II number 1 of MPR Decree No. VI / MPR / 2001).[18]

Pancasila education as an understanding of ideology as stated in Law No.12 of 2012 concerning higher education is expected to strengthen student academic modalities in participating in building public understanding, including the need for awareness of a simple lifestyle and love for domestic products, awareness of the importance of survival for future generations, Awareness of the importance of the spirit of national unity (solidarity), awareness of the importance of social norms, awareness of the importance of national mental health, awareness of the importance of law enforcement, instilling the importance of awareness of the ideology of Pancasila.[19]

Presidential Regulation No. 8 of 2018 concerning the Indonesian National Qualifications Framework outlines that the attitude / character possessed by all levels expects to have a devoted attitude to God Almighty, be moral and act well in society, work together regardless of ethnic origin, religion and race, being proud of their homeland, acting as agents of peace building both at home and abroad, and respecting various religions, races, ethnicities, the spirit of fighting for the interests of the nation and state.[20]

To face challenges and anticipate the future Pancasila education should also be able to provide a basic basis for the need to prepare human resources who have global and world-class competitiveness who have honest integrity and have a sense of nationality and nationalism, are professional, have global insight, master information technology and foreign languages, has an entrepreneurial spirit (entrepreneurship), is friendly and serves (hospitality) and has a strong network power regardless of ethnic origin, religion and race.

Pancasila Education Learning is also directed at character building as stipulated by MPR Decree No. VII / MPR / 2001 Regarding the Vision of a Future Indonesia, which in essence states that to measure the success rate of the realization of the Vision of Indonesia 2020, the main indicators are used which essentially reflect the values of Pancasila, namely (1) Religious, namely those who are faithful, pious, moral. noble, and honest, tolerance between and between religious communities, (2) Humane, namely respecting human values, regardless of cultural, ethnic, racial, religious backgrounds and others, (3) Unity, namely practicing the spirit of national unity and harmony (4) Democratic, namely the existence of a balance of power between state administering institutions and a balance of power relations between the central and regional governments; (5) Fair, namely without discrimination; all legal institutions and apparatus must be clean and professional; fair and balanced human rights enforcement.[21]

\subsection{LEGAL POLITICS LEARNING STRATEGIES IN INSTALLING PANCASILA VALUE CHARACTERS IN THE TIME OF COVID-19}

Education in Indonesia should produce human resources (HR) with the character of Pancasila. However, based on the results of the study, it shows that there is a lack of internalization of the values and morals of Pancasila, so that significant changes, improvements and arrangements are needed in the educational unit. Therefore it is necessary to make changes in learning management policies that are oriented towards the planning process of vision, mission, and goals (Center for curriculum and learning of the Research and Development Agency of the Ministry of Education and Culture, 2019).[22]

The joint decree of the Ministry of Education and Culture, Ministry of Religion, Ministry of Health and Ministry of Home Affairs regarding guidelines for organizing learning for the new academic year and academic year during the covid-19 period states that the academic year of Higher Education 2020/2021 will still start in August 2020, the year academic higher education of religion2020/2021 in September 2020.[23] Learning methods in tertiary institutions in all zones must be implemented online for theoretical courses, as well as for practical courses as far as possible to continue online. In the event that a course cannot be implemented online, the course is placed at the end of the semester. Based on this, higher education leaders in all zones can only allow student activities on campus if they meet health protocols and policies that will be issued by the related director general for activities that are not can be replaced with online learning, such as laboratory research for theses, theses and dissertations, laboratory assignments, practicum, studios, workshops, and similar academic / vocational activities. [24]

Because the Pancasila course is a course that internationalizes the values contained in it, it is actually more effective if it is done face-to-face, but because of the conditions of Covid 19 it is still implemented online. To do this, strategic steps must be taken, namely (1) determine the learning outcomes of graduates that can be taken from Permendikbud No.3 of 2020 concerning National Higher Education Standards regarding general attitudes and skills, (2) Determine the learning outcomes of courses that have been decided by the association or authorized official, (3) determine the substance of the 
study / material lectures, (4) determine the implementation of learning with online methods that are in accordance with the material and course outcomes to be achieved, (5) determine the evaluation.[25]

Regarding the online learning method in instilling the values of Pancasila character values, it can be used with the following model (1) instructional videos with PowerPoint / Lecturer animation create teaching materials in PowerPoint (or 2D / 3D animation media) as well as recording audio narration to be conveyed as description of the visual display. After the PPT has been made, it is exported into a video file (mp4), (2) a video lesson with a non-narrative video / film approach. This video is made with a filmic approach as it is making video shows / news films / tutorials / documentaries. story (lecturer) / Voice Over from the narrator explaining the video / film, (3) video learning with the Narrative Video / Film approach This video is made with a filmic approach similar to making a video show / story film / semidocumentary Usually made by presenting a story equipped with the characters in the video / film.

\section{CONCLUSION}

Pancasila education courses in the learning process must be able to develop student awareness of the understanding of the Pancasila ideology and its values. In the learning process in Higher Education it is the responsibility of all course holders to develop the student's awareness. For that, the right steps are needed, namely determining graduate learning outcomes, namely attitudes, general skills, course learning outcomes and online or online-based learning methods that are able to foster understanding of the Pancasila ideology and the character values contained in Pancasila.

Pancasila is a value system that is extracted from the noble values of the Indonesian nation. The noble values as the foundation for the national character of each ethnic group in Indonesia are as follows: 1) Religious; 2) Honest, 3) Tolerance; 4) Discipline, 5) Hard work; 6) Creative; 7) Independent; 8) Democratic; 9) Curiosity; 10) National spirit; 11) Love the motherland; 12) Appreciate achievements; 13) Friendly / communicative; 14) Love peace; 15) Like to read; 16) Social care; 17) Care for the environment; 18) Responsibility (Sriyono, 2010). These values have existed long before Indonesia's independence. Even during the kingdom era, the basic values which were the character of Indonesian society [26] Pancasila values should be attached to our life pattern because the values of Pancasila itself cover the people, nation and state of Indonesia. Pancasila is also a value that is in accordance with the conscience of the Indonesian people, because it is rooted in the national personality. Pancasila values become motivation in overcoming all existing problems.

The basic values of Pancasila include divinity, humanity, unity, democracy, and justice which are universal and objective, meaning that these values can be used and recognized by other countries. Pancasila is also subjective, which means that the values of Pancasila are attached to the bearers and supporters of the values of Pancasila itself, namely the society, nation and state of Indonesia.[27] Character education aims to develop values that shape the character of the nation, namely Pancasila, including: (1) developing the potential of students to become human beings with good hearts, good thoughts, and good behavior; (2) building a nation characterized by Pancasila; (3) developing the potential of citizens to have a confident attitude, be proud of their nation and country and love humanity.[28] In addition, character education also aims to shape a person's personality so that they behave honestly, well and responsibly, respect and respect others, fair, nondiscriminatory, egalitarian, hardworking and other superior characters.[29] Getting used and practicing in real life will greatly help achieve the goals of character education. From this description it can be concluded that character education, character education, moral education, value education, which is carried out consciously, systematically and is aimed at developing a person's or students' abilities so that they can decide and practice goodness in their daily lives such as being responsible, honest, working hard. and respect for others is the definition and purpose of character education.[30]

During the Covid-19 Pandemic, it was necessary to reestablish the values of Pancasila so that it remains the study of the younger generation, especially students, one of which can be started from education in Indonesia, for example from elementary school education. This is because Pancasila is closely related to character education. The implementation of Pancasila values during the Covid19 period for students can be carried out by fostering a disciplined and responsible nature for the online learning process. A sense of discipline and responsibility can be reinstated in the learning process. Teachers who sincerely teach well and sincerely guide students to be able to make achievements in pandemic diamas. Students who study seriously with all their abilities for the good name of the nation and state. Not only that, a sense of nationalism can also be built through the work of students entitled fighting spirit for the country.

Fostering a strong spirit of nationalism, for example the spirit of loving domestic products. Instill and practice the values of Pancasila as well as possible. Instilling and implementing religious teachings as well as possible. Realizing the rule of law, implementing and enforcing the law in the true and fairest sense. Be selective about the influence of globalization in the political, ideological, economic, and socio-cultural fields of the nation.

\section{ACKNOWLEDGMENT}

This work was supported by Universitas Sebelas Maret, Surakarta, Indonesia. 


\section{REFERENCES}

[1] Fraenkel, Jack R. 1977. How to Teach about Values: An Analytical Approach, Englewood, NJ: Prentice Hall. pp. 1-2

[2] Law No. 20 of 2003 concerning the National Education System.

[3] Pustaka, R. K. (2004). UUD 1945 and its amendments. Jakarta: Friends of the Library.

[4] Purnadi Purbacaraka and Soerjono Soekanto, 1982, Joints of Legal Studies and Law Administration, Bandung: Alumni.

[5] Zed, M. 2008. Literature Research Methods, Yayasan Obor Indonesia, Jakarta.

[6] Harahap, N. 2014. Literature Research, Iqra Journal, Vol. 08, No. 01, Pages 68-74.

[7] Keosoema, Doni. 2010. Integral Character Education. Kompas, 11 February 2010.

[8] Fraenkel, Jack R. 1977. How to Teach about Values: An Analytical Approach, Englewood, NJ: Prentice Hall. pp. 2.

[9] Phillips, C. Thomas. 2000. Family as the School of Love. Paper at the National Conference on Character Building, Jakarta, 25-26 November, 2000, pp. 11.

[10] Shihab, M. Quraish. 1996. Insights of al-Qur'an: Maudhu'I Interpretation of Various Problems of the Ummah. Bandung: Mizan, pp. 321.

[11] Institute for the Study and Development of State Life. 2005. General Guidelines for the Implementation of Pancasila in State Life. Jakarta: LPPKB.

[12] Mariatun, Ika Lis. (2019). Strengthening Pancasila-Based Character Education through the K13 Curriculum in Elementary Schools. Journal of Civics and Socio-Cultural Education. 153-160

[13] Murphy, M. (1998). Character Education in America's Blue Ribbon Schools. Lancaster PA: Technomic.

[14] Susanti, R. (2013). Implementation of Character Education Among Students. Journal of Al-Ta'lim, 1 (6), 480-487. https://doi.org/10.37092/ej.v1i1.89.

[15] Irhandayaningsih, Ana. (2012). The Role of Pncasila in Fostering Youth Nationalism Awareness in the Global Era. Diponegoro University.
[16] Kristiono, Natal. (2018). Emphasis of Pancasila Ideology among Semarang State University Students. Pancasila and Citizenship Journal. Vol 2 (02).

[17] Law No. 20 of 2003 concerning the National Education System.

[18] RI MPR Decree No. VI / MPR / 2001

Regarding Ethics of National Life. Jakarta: State Secretariat.

[19] Law No. 12 of 2012 concerning Higher Education.

[20] Presidential Regulation of the Republic of Indonesia No. 8 of 2012 concerning the Indonesian National Qualifications Framework.

[21] RI MPR Decree No. VII / MPR / 2001

Regarding Indonesia's Vision for the Future. Jakarta: State secretariat

[22] Curriculum and learning center Research and development agency. 2019. Strengthening learning of Pancasila values and morals. Jakarta: kemendikbud.

[23] RI Government. 2010. Master Design for National Character Development, 2010-2025. Jakarta: Government of the Republic of Indonesia.

[24] Joint Decree of the Ministry of Education and Culture, Ministry of Religion, Ministry of Health, Ministry of Home Affairs. 2019 regarding Guidelines for implementing learning in the new academic year and academic year during the Covid-19 pandemic.

[25] Permendikbud No. 3 of 2020 concerning National Higher Education Standards.

[26] Wira. (2017). Consolidating Pancasila Values to the Young Generation as the True National Self. Jakrata: Public Puskom Kemhan.

[27] Asmaroini, Ambiro Puji. (2016).

Implementation of Pancasila Values for Students in the Age of Globalization. Pancasila and Citizenship Journal. Vol. 4 (02).

[28] Kemendiknas. (2011). Character Education Guide. Jakarta: Ministry of National Education Curriculum and Book Center. 
[29] Mahmud, A. (2005). Contemporary Islamic

Thought in Indonesia. Yogyakarta: Student

Library.

[30] Bush, Tony and Les Bell, The Principles and

Practice of Educational Management, (London: A.

SAGE Publications Company, 2002), First

Published. 